\title{
Optimizing Micropropagation Protocol for Rosa hybrida cv. Eiffel Tower with Improved in vitro Rooting Ability
}

\author{
Azza A. Tawfik*, O.H.M. Ibrahim*, E.Y. Abdul-Hafeez*, Samar A.I. Ibrahim** \\ *Ornamental Plants and Landscape Gardening Department, Faculty of Agriculture \\ and ${ }^{* *}$ Horticulture Department, Faculty of Agriculture, New Valley Branch, Assiut \\ University, Egypt.
}

\begin{abstract}
$\mathrm{I}_{\mathrm{p}}^{N}$ $N$ VITRO propagation techniques were studied to establish a protocol for rapid and mass production of Rosa spp. cv. Eiffel Tower, an important and endangered cultivar. Several experiments were conducted through a two-stage procedure: multiplication stage and rooting of microshoots stage. For multiplication, the best results were obtained when nodal segments were cultured on MS medium supplemented with BAP at $1 \mathrm{mg} / 1 \mathrm{and} /$ or Kinetin at $0.5 \mathrm{mg} / 1$. The highest shoots number (3.17 shoots/explant) was obtained when $0.5 \mathrm{mg} / 1 \mathrm{BAP}$ was added to the medium. Kinetin at $0.5 \mathrm{mg} / 1$ produced the highest shoot number/explant ( 3.67 shoots), and shoot length $(3.67 \mathrm{~cm})$. The interaction between BAP at $1 \mathrm{mg} / 1 \mathrm{plus}$ kinetin at $0.5 \mathrm{mg} / \mathrm{l}$ gave the highest shoot number/explant (4 shoots). For rooting, the best interaction effect on rooting percentage $(61.00 \%)$, highest number of roots/shoot $(5.12)$ and root length $(3.33 \mathrm{~cm})$ were observed when the shoots were cultured on hormone-free MS medium and $\mathrm{pH}$ level was adjusted to 5.5. Moreover, adjusting the medium $\mathrm{pH}$ to 5.5 formed roots faster in 17.67 days followed by medium with $\mathrm{pH}$ level 4.5 (18 days). The medium with $\mathrm{pH}$ at 5.5 supplemented with $50 \mathrm{~g} / 1$ sucrose produced the highest significant value of rooting $(85 \%)$ and enhanced root formation in 7.5 days. The rooted plantlets were transplanted into the potting substrate and successfully acclimatized in the laboratory then transferred to the field with a survival rate of $55 \%$. After 6 month, the plantlets reached $\sim 22 \mathrm{~cm}$ in length and 5.50 leaves/plant
\end{abstract}

Keywords: Rose, MS medium pH, Nodal segments, Sucrose, Kinetin, BAP

\section{Introduction}

The genus Rosa belongs to family Rosaceae and includes more than 100 species and thousands of cultivars of economical and commercial perennial shrubs and climbers. Of the several major classes belonging to garden roses, hybrid tea is the best-known and most-popular class. It is the source of the majority of rose cultivars grown in greenhouses, gardens and sold in the florist market, which are known for their beauty and mostly fragrant flowers. One of the most popular and preferable cultivars of hybrid tea roses in the Egyptian market is 'Eiffel Tower'. This cultivar was obtained via hybridization by David Armstrong and Herbert Swim. It was registered and introduced in 1963 (Rose Society, 2012). It is characterized by its tolerance to hot and dry Mediterranean climate in addition to its fragrant pink flowers which appear throughout the entire growing season.
Like many other rose cultivars, 'Eiffel Tower' is propagated by vegetative means (grafting and stem cuttings) even though it does not ensure mass production of healthy and diseasefree plants (Kroin, 2016 and Manners, 2014). Different species are commercially propagated using tissue culture techniques. Micropropagation is a fast propagation method and offers a potential to deliver enormous quantities of true-to type and disease-free plants within a short span of time (Brunda et al., 2016). So, tissue culture can be used as substitute to traditional production methods.

Since the first report of Hasegawa (1979) on micropropagation of Rosa hybrida L. by proliferation of axillary buds, different methodologies have been applied for in vitro propagation of many species and cultivars of roses (Ibrahim \& Debergh, 2001, Schum et al., 2001, Pati et al., 2006, Kumud et al., 2015, Uzunova,

*Corresponding author: O.H.M. Ibrahim, e-mail: omer_hooo@yahoo.com

DOI: 10.21608/ejoh.2018.4906.1075

C2017 National Information and Documentation Centre (NIDOC) 
2015, Ambros et al., 2016 and Kumari et al., 2017) and many commercial laboratories have been established all over the world for mass production of such important ornamental cut flowers to meet the market demand. The success of micropropagation involves several factors viz., the composition and type of the culture medium (Tawfik et al., 1992 and Bagheri et al., 2015), culture environment (Schum et al., 2001 and Tawfik and Mohamed, 2005), genotype (Tawfik \& Mohamed, 2006 and Hamama et al., 2015), explant type (Tawfik \& Noga, 2001 and Maurya et al., 2013).

In plant micropropagation, type and concentration of plant growth regulators play a major role in cell division, differentiation and morphogenesis (Tawfik, 1995 and 1997). In addition, the successful regeneration of shoots and their subsequent rooting is essential for the commercial exploitation of micropropagation technology (McGaw \& Burch, 1995 and Mahmood \& Hauser, 2015).

Nevertheless, there is scarce available information about the use of micropropagation technique for Rosa hybrida cv. Eiffel Tower. Thus the aim of this study is to encourage the expansion of cultivation of such cultivar and the production of high quantities of genetically homogenous plants by tissue culture techniques through the establishment of an efficient protocol for in vitro propagation of such important and cultivar with special emphasis on enhancing in vitro rooting ability.

\section{Materials and Methods}

\section{Plant material}

Young and healthy shoots of Rosa hybrida cv. Eiffel Tower were collected from mature shrubs growing in the farm of Floriculture and Medicinal plants, Faculty of Agriculture, Assiut University during 2017 and 2018 seasons. The subterminal part of the shoots $(10-15 \mathrm{~cm}$ in length) were defoliated and used to prepare the explants as single nodes $(1.5-2 \mathrm{~cm})$.

\section{Culture establishment}

The excised explants were thoroughly washed with running tap water, then an experiment was carried out to investigate the effect of disinfestation with various concentrations and duration of commercial bleach $\sim 5 \%$ sodium hypochlorite (data are not shown). As a result of a preliminary trail $100 \%$ of the commercial bleach for 10 minutes was applied. The containers which contained the explants and the bleach were thoroughly shaken. Then the explants were rinsed 4 times with sterile distilled water. After the surface disinfestation, the explants were cultured into $350 \mathrm{ml}$ sterilized glass jars, containing $50 \mathrm{ml}$ of assigned medium MS nutrient medium (Murashig and Skoog, 1962) was used in all experiments conducted in the course of the current study. The media were solidified with $8 \mathrm{~g}$ agar/l, sucrose was added at the rate of $30 \mathrm{~g} / \mathrm{l}$ and the $\mathrm{pH}$ was adjusted to $5.8 \pm 0.1$ in all experiments except where different levels of $\mathrm{pH}$ and sucrose were investigated. All the tested media were autoclaved at $121^{\circ} \mathrm{C}$ and $1.2 \mathrm{~kg} / \mathrm{cm}^{2}$ for $20 \mathrm{~min}$. All the cultured jars were incubated in a plant growth room at $25 \pm 22^{\circ} \mathrm{C}$ under constant fluorescent light of 1500 Lux for 16/8 h (light/ dark) photoperiod.

\section{Multiplication stage experiments}

An experiments was conducted to study the effect of different plant growth regulators on proliferation of the Rosa hybrida cv. Eiffel Tower explants transferred from 4-week old culture on the same medium from the previous stage. The experiment was conducted to test the effect of 6-Benzylaminopurine (BAP) at different concentrations $(0.0,0.5,1.0$ and $2 \mathrm{mg} / \mathrm{l})$ and Kinetin at 0.0 and $0.5 \mathrm{mg} / \mathrm{l}$ on proliferation ability. The experiment was designed as a factorial experiment in a randomized complete block design (RCBD) with 3 replicates and 15 jars for each treatment each jar containing 2 explants. Data were measured after 4 weeks on shoot proliferation, shoot number per explant, shoot length $(\mathrm{cm})$, shoot fresh weight $(\mathrm{g})$ and shoot dry weight $(\mathrm{g})$.

\section{Rooting stage}

The main goal at this stage was to enhance the micro-shoots (from the multiplication stage cultured on the same medium) to induce roots and obtain complete plantlets to be hardened and transferred to the field with a minimum loss. So, shoots (2-3 cm in length) were transferred to basal MS medium for root induction. Three experiments were carried out. In the first experiment, MS medium was used with 5 levels of $\mathrm{pH}(4.0,4.5,5.0,5.5$ and 5.8) supplemented with NAA at different concentrations $(0.0,0.1$ and $0.2 \mathrm{mg} / \mathrm{l})$. It was designed as a factorial $(5 \times 3)$ in a completely randomized design (CRD) with 3 replicates and 15 jars for each treatment. The second experiment was designed to test the effect of different concentrations of sucrose $(0.0,30,40$ 
and $50 \mathrm{~g} / \mathrm{l}$ ) on rooting of Rosa hybrida cv. Eiffel Tower. Half-strength MS medium was solidified with $8 \mathrm{~g} / \mathrm{l}$ agar (w/v) and the $\mathrm{pH}$ of the medium was adjusted to $5 \pm 0.01$. A completely randomized design (CRD) was used with 3 replicates and 15 jars for each treatment. In the third experiment, the effect of MS medium $\mathrm{pH}$ (5 and 5.5) and sucrose concentrations $(30,40$ and $50 \mathrm{~g} / \mathrm{l})$ on rooting was studied. This experiment was designed as a factorial experiment in randomized complete block design with 3 replicates and 15 jars for each treatment. Data were recorded starting from the second week after culturing and followed up until the fourth week on rooting $\%$, roots number per shoot, root length $(\mathrm{cm})$ and number of days to form roots.

\section{Acclimatization stage}

Healthy and well rooted plantlets of Rosa 'Eiffel Tower' obtained from the previous stage were selected and taken away from jars, then their roots were thoroughly washed with tap water to eliminate the agar. These plantlets were transferred to plastic pots filled with peat moss and perlite $1: 1(\mathrm{v} / \mathrm{v})$. The pots were covered with clear polyethylene bags to maintain high relative humidity and then kept in the growth room for $\sim 3$ weeks. The plants were watered with tap water each 2 days. Then the polyethylene bags were removed and the plants were transferred to the green house. Data were recorded on survival percentage, shoot length and leaves number per shoot.

\section{Statistical analysis}

Data of all experiments were subjected to analysis of variance (ANOVA) and mean comparison were performed using the least significant difference (LSD) methods with a significant level of 5\% according to (Gomez and Gomez, 1984)

\section{Results and Discussion}

\section{Multiplication stage}

Preliminary trials were conducted to determine the most proper concentration of both BAP and Kin for shoot multiplication (data not shown). It was found that BAP at 0.5 and $1 \mathrm{mg} / \mathrm{l}$ and Kin at $0.5 \mathrm{mg} / 1$ showed the best proliferation rate of in vitro grown explants of the cultivar 'Eiffel Tower'. Both cytokinin types were involved together in order to study their solitary and combined effect.

As shown in Tables 1 and 2 and Fig.1, the interaction effect of kinetin and BAP on all the growth measurements instigated significant differences. Shoot multiplication and their fresh and dry weights of shoots were significantly enhanced when nodal segments were cultured on MS medium supplemented with BAP at $1 \mathrm{mg} / \mathrm{l}$ plus Kin at $0.5 \mathrm{mg} / \mathrm{l}$. The same combined treatment gave the highest shoot number per explant (4 shoots) followed by the medium supplemented with Kin and BAP both at $0.5 \mathrm{mg} / 1$ which produced 3.67 shoots per explant. These results are consistent with the previous observations reported by Kanchanapoom et al. (2009), Hegde et al. (2011) and Kharde \& Kshirsagar (2014). MS medium supplemented with Kin at $0.5 \mathrm{mg} / \mathrm{l}$ and BAP at $1 \mathrm{mg} / \mathrm{l}$ gave the highest fresh and dry weights of shoots $(0.35 \mathrm{~g}$ and $0.08 \mathrm{~g}$ respectively). Tawfik (2002), has shown an increased efficacy of medium supplemented with both BAP and TDZ (thidiazuron, a cytokinin-like substance) in regeneration of Salvia officinals. The stimulation effect has been attributed to possible complementary action. However, both BAP and Kin decreased the shoot length (Tables 1 and 2). These results could be interpreted according to the general fact that cytokinins stimulate shoot proliferation and inhibit their elongation. Moreover, strong cytokinins such as BAP depress shoot length by an increase in number of axillary buds (Hameed et al., 2006) where the formation of lateral shoots utilize all the nutrients (Yakimova et al., 2000). Other investigators such as Ahmad et al. (2003) concluded that the high cytokinin concentration causes an increase in the ethylene level in plants which block the basipetal transport of endogenous auxin in the shoots resulting in the minimum shoot length.

\section{Rooting stage}

Shoots obtained from the multiplication stage were transferred to MS basal medium for rooting induction.

\section{Effect of medium $p H, N A A$ concentrations and their interaction}

It could be inferred from the data presented in Table 3 that the influence of NAA was affected by the medium $\mathrm{pH}$, where no response was observed on a medium with $\mathrm{pH} 4$. While adding NAA at different concentrations to a medium with $\mathrm{pH}$ level of 5.8 (the standard level recommended by Murashig and Skoog, 1962) led to the formation of callus. Data presented in Tables 3 and 4 indicate that adding NAA to the rooting medium decreased all the measured growth parameters. This is maybe attributed to the change of the medium $\mathrm{pH}$ to $4.5,5$ and 5.5 .

Concerning the effect of medium $\mathrm{pH}$ on the Egypt. J. Hort. Vol. 45, No. 2 (2018) 
rooting measurements, it is clear that at medium $\mathrm{pH} 4$ no response was observed while at the standard $\mathrm{pH}$ level (5.8) recommended for $\mathrm{MS}$ medium, callus was formed on the shoot base (Table 3 and 4). Adjusting the medium $\mathrm{pH}$ to levels 5 and 5.5 produced the highest root percentage (55.22 and 53.44\%), root number (3.20 and 3.48 roots per shoot) and root length (2.08 and 2.40 $\mathrm{cm})$ respectively with no significant differences between these two levels of $\mathrm{pH}$. However, medium with $\mathrm{pH} 5.5$ significantly enhanced forming roots in 21.89 days compared to medium $\mathrm{pH}$ at 5 where roots were formed in 25.11 days. Similar results were reported by Martins et al. (2011) on Plantago Imogravensis, Kovacevic et al. (2013) on poplar. Also, Ahmed et al. (2014) reported that Musa spp. produced the longest roots in the shortest time when the medium $\mathrm{pH}$ was adjusted to 5.5. The reasons behind the stimulating effect of the $\mathrm{pH}$ levels lower than 5.8 may be attributed to the increased initial uptake of micronutrients at low $\mathrm{pH}$ as suggested by Van Winkle and Pullman
(2003) and the increased initial uptake of auxins at low $\mathrm{pH}$ according to the results demonstrated by De Klerk et al. (2008). Other investigators, such as Shang et al. (1991), stated that the effect of the initial $\mathrm{pH}$ on the developmental fate of the cell culture indicates that complicated action-reaction processes between the cells and the extracellular $\mathrm{pH}$ must occur.

As shown in Tables 3 and 4, the highest rooting percentages $(62.67 \%$ and $61.00 \%)$ were recorded when the shoots were cultured on free-hormoneMS medium and $\mathrm{pH}$ level was adjusted to 5 and 5.5 , respectively. Moreover, adjusting the medium $\mathrm{pH}$ to 5.5 produced the highest number of roots $(5.12$ roots per shoot) and root length $(3.33 \mathrm{~cm})$. Shoots cultured on hormone-free medium with $\mathrm{pH}$ adjusted to 5.5 formed roots faster in 17.67 days followed by medium with $\mathrm{pH}$ level 4.5 (18 days).

TABLE 1. Effect of Kin and BAP on shoot number/explant and average shoot length during in vitro multiplication stage of Rosa hybrida cv. Eiffel Tower nodal segments

\begin{tabular}{|c|c|c|c|c|c|c|}
\hline \multirow{3}{*}{ BAP } & \multicolumn{3}{|c|}{ Shoot number/explant } & \multirow{2}{*}{\multicolumn{3}{|c|}{$\begin{array}{c}\text { Shoot length } \\
(\mathrm{cm})\end{array}$}} \\
\hline & & & & & & \\
\hline & 0.0 & 0.5 & Mean & $\mathbf{0 . 0}$ & 0.5 & Mean \\
\hline 0.0 & 0.97 & 1.67 & 1.32 & 5.40 & 3.60 & 4.50 \\
\hline 0.5 & 2.00 & 3.67 & 2.84 & 3.00 & 3.00 & 3.00 \\
\hline 1.0 & 2.00 & 4.00 & 3.00 & 2.00 & 1.67 & 1.84 \\
\hline Mean & 1.66 & 3.11 & & 3.57 & 2.76 & \\
\hline \multicolumn{7}{|l|}{ LSD 5\% } \\
\hline Kin & & 0.57 & & & 0.17 & \\
\hline BAP & & 0.69 & & & 0.21 & \\
\hline Kin $x$ BAP & & 0.98 & & & 0.30 & \\
\hline
\end{tabular}

TABLE 2. Effect of Kin and BAP on shoot fresh and dry weights (g) during in vitro multiplication stage of Rosa hybrida cv. Eiffel Tower nodal segments

\begin{tabular}{|c|c|c|c|c|c|c|}
\hline \multirow{2}{*}{ BAP } & \multicolumn{2}{|c|}{ Fresh weight } & & \multicolumn{3}{|c|}{$\begin{array}{c}\text { Dry weight } \\
\text { (g) }\end{array}$} \\
\hline & 0.0 & 0.5 & Mean & 0.0 & 0.5 & Mean \\
\hline 0.5 & 0.24 & 0.27 & 0.26 & 0.05 & 0.03 & 0.04 \\
\hline 1.0 & 0.18 & 0.35 & 0.27 & 0.04 & 0.08 & 0.06 \\
\hline Kin & & 0.02 & & & 0.01 & \\
\hline BAP & & 0.02 & & & 0.02 & \\
\hline Kin $x$ BAP & & 0.03 & & & 0.02 & \\
\hline
\end{tabular}

Egypt. J. Hort. Vol. 45, No. 2 (2018) 


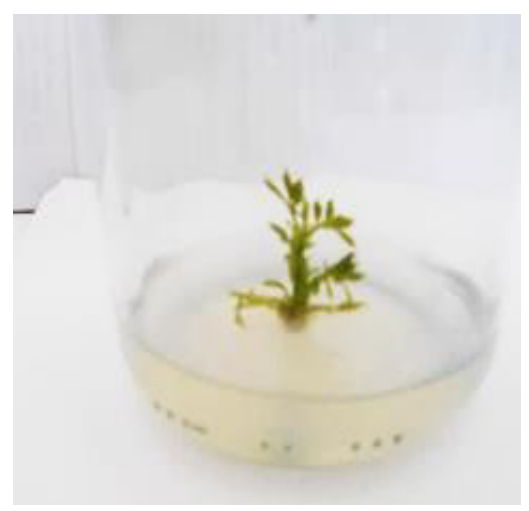

Control

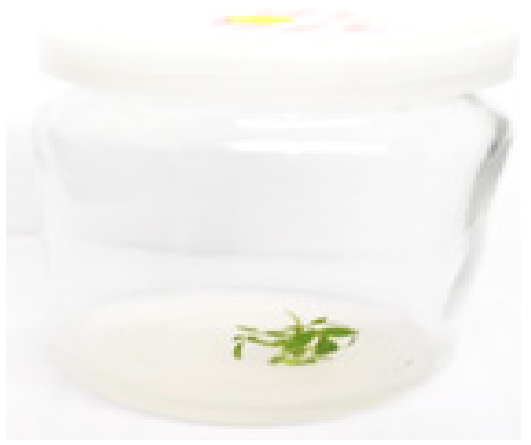

$1 \mathrm{mg} / \mathbf{l}$ BAP

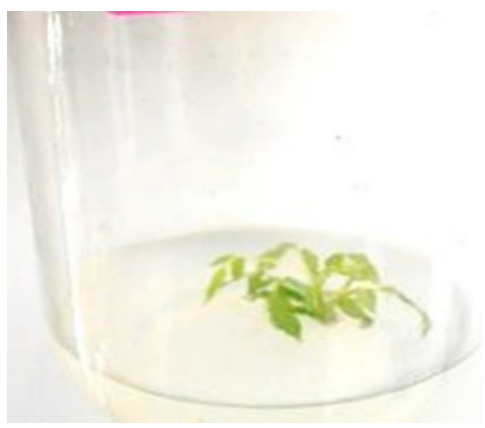

mg/l Kin 1

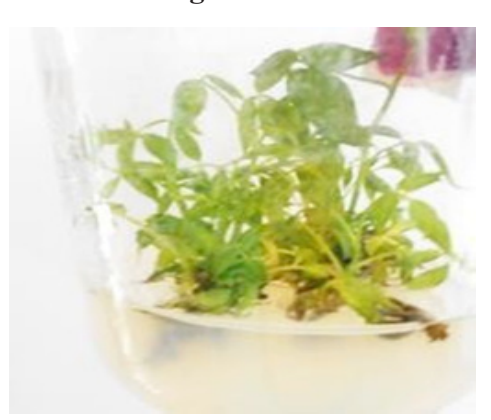

$0.5 \mathrm{mg} / \mathrm{l} \mathrm{Kin} \mathrm{+1} \mathrm{mg/l} \mathrm{BAP}$

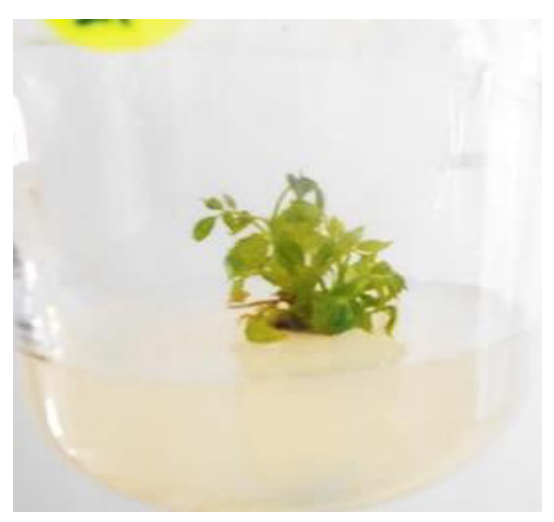

mg/l BAP 0.5

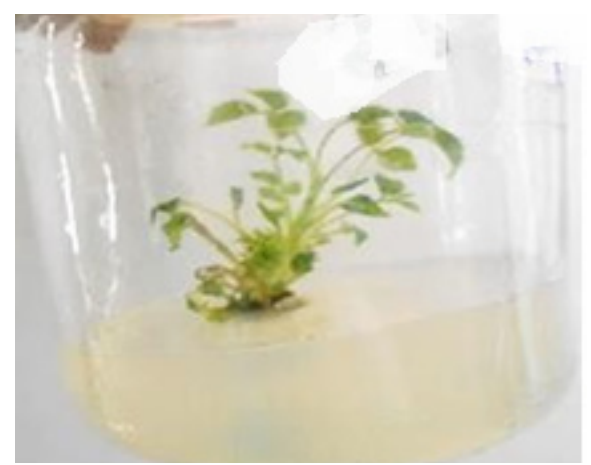

mg/l Kin 0.5

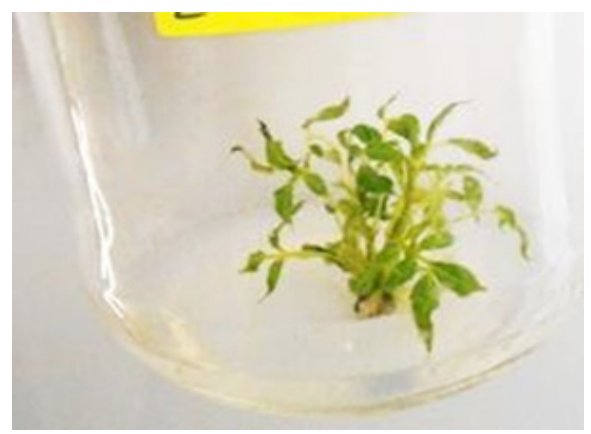

$\mathrm{mg} / \mathrm{l} \mathrm{Kin}+0.5 \mathrm{mg} / \mathrm{l} \mathrm{BAP} 0.5$

Fig. 1. Effect of interaction between BAP and kinetin at different concentrations on proliferation of Rosa hybrida cv. Eiffel Tower nodal segments 
TABLE 3. Effect of medium pH and NAA on rooting\% and number of roots during in vitro rooting stage of Rosa hybrida. cv. Eiffel Tower

\begin{tabular}{|c|c|c|c|c|c|c|c|c|}
\hline \multirow{2}{*}{ pH NAAmg/l } & \multicolumn{4}{|c|}{ Rooting\% } & \multicolumn{4}{|c|}{ Number of roots } \\
\hline & 0.0 & 0.1 & 0.2 & Mean & 0.0 & 0.1 & 0.2 & Mean \\
\hline 4.0 & - & - & - & - & - & - & - & - \\
\hline 4.5 & 42.33 & 47.33 & 52.67 & 47.44 & 5.33 & 4.17 & 2.00 & 3.83 \\
\hline 5.0 & 62.67 & 49.00 & 54.00 & 55.22 & 4.33 & 3.67 & 1.60 & 3.20 \\
\hline 5.5 & 61.00 & 47.33 & 52.00 & 53.44 & 5.12 & 3.33 & 2.00 & 3.48 \\
\hline 5.8 & Callus & Callus & callus & & callus & callus & callus & \\
\hline Mean & 55.33 & 47.89 & 52.89 & & 4.93 & 3.72 & 1.87 & \\
\hline \multicolumn{9}{|l|}{ LSD 0.05} \\
\hline $\mathrm{pH}$ & & 2.05 & & & & 0.42 & & \\
\hline NAA & & 2.05 & & & & 0.47 & & \\
\hline $\mathrm{pH} \times \mathrm{NAA}$ & & 3.55 & & & & 0.72 & & \\
\hline
\end{tabular}

TABLE 4. Effect of medium $\mathrm{pH}$ and NAA on root length and number of days to form roots during in vitro rooting stage of Rosa hybrida. cv. Eiffel Tower

\begin{tabular}{|c|c|c|c|c|c|c|c|c|}
\hline \multirow{2}{*}{ pH NAAmg/l } & \multicolumn{4}{|c|}{ Root length $(\mathrm{cm})$} & \multicolumn{4}{|c|}{ Number of days to form roots } \\
\hline & 0.0 & 0.1 & 0.2 & & 0.0 & 0.1 & 0.2 & Mean \\
\hline 4.0 & - & - & - & - & - & - & - & - \\
\hline 4.5 & 1.33 & 0.83 & 0.83 & 0.99 & 18.00 & 22.33 & 27.67 & 22.67 \\
\hline 5.0 & 3.33 & 2.07 & 0.83 & 2.08 & 27.00 & 27.00 & 21.33 & 25.11 \\
\hline 5.5 & 3.33 & 2.00 & 1.87 & 2.40 & 17.67 & 20.67 & 27.33 & 21.89 \\
\hline 5.8 & callus & callus & callus & & callus & callus & callus & \\
\hline Mean & 2.66 & 1.63 & 1.18 & & 20.89 & 23.33 & 25.44 & \\
\hline \multicolumn{9}{|l|}{ LSD 0.05} \\
\hline $\mathrm{pH}$ & & 0.35 & & & & & 2.51 & \\
\hline NAA & & 0.14 & & & & & 2.51 & \\
\hline $\mathrm{pH} \times \mathrm{NAA}$ & & 0.61 & & & & & 4.35 & \\
\hline
\end{tabular}

Effect of different concentrations of sucrose on rooting behavior

The response of the microshoots of Rosa hybrida cv. Eiffel Tower cultured on half-strength MS medium with $\mathrm{pH} 5$ at different concentrations of sucrose is illustrated in Fig. 2. Elimination of sucrose completely from the rooting medium cause a significant reduction in rooting percentage, number of roots and root length, while number of days to form roots significantly increased. Similar results were reported by Tawfik (1995), who stated that thin and weak roots were formed after 35 days on the basal end of Melaleuca armillaris explant cultured on sucrose-free MS medium. Raising the sucrose concentration up to $50 \mathrm{mg} / \mathrm{l}$ significantly increased rooting $\%$, root number, root length and, moreover, reduced the time to form roots. It is obvious that $82.33 \%$ of cultures formed roots in 7.33 days when $50 \mathrm{~g}$ sucrose/l was added to the medium comparing with the medium containing $30 \mathrm{~g}$ sucrose $/ 1$ which had rooting percentage $(62.33 \%)$ formed within 14.67 days. Similar results were found by Hasan et al. (2015) and Gabryszewska (2015) who reported that using $50 \mathrm{~g} / 1$ sucrose strongly simulated the number of roots per shoot (5.8-6.0 roots) in Helleborus niger. 

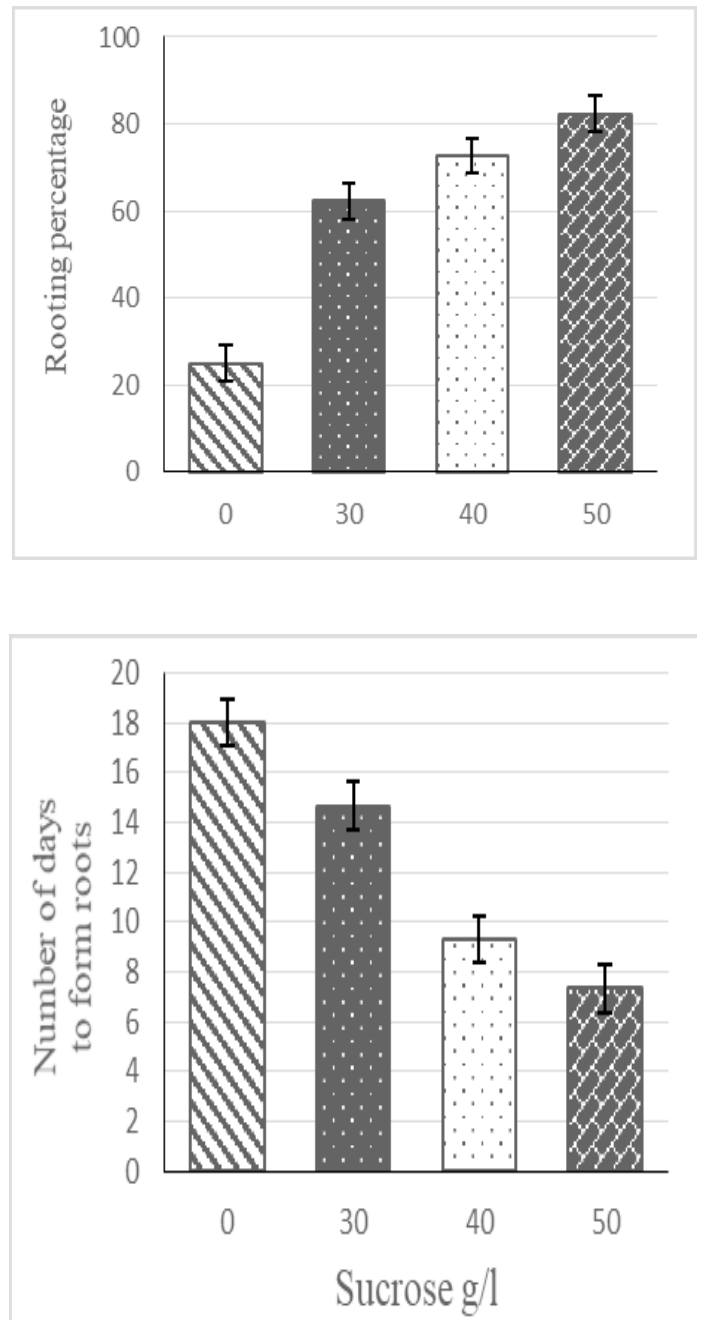

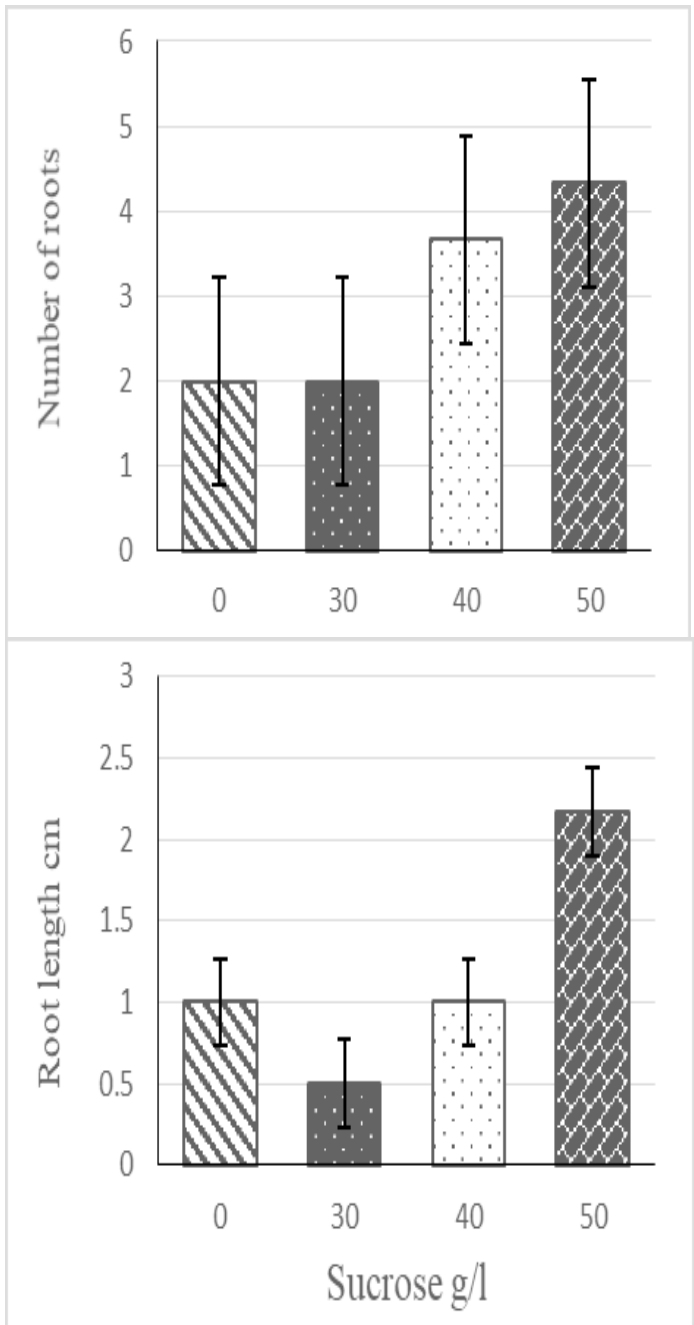

Fig. 2. Effect of sucrose concentrations on rooting behavior of Rosa hybrida. cv. Eiffel Tower shoots. Vertical bars indicate LSD at $\boldsymbol{P}=\mathbf{0 . 0 5}$

Effect of medium $\mathrm{pH}$ and sucrose concentrations on rooting behavior

This experiment was conducted to test the effect of $\mathrm{pH}$ medium at 5 and 5.5 and different concentrations of sucrose (30, 40 and $50 \mathrm{mg} / \mathrm{l})$ as well as their interactions on rooting percentage, root number, root length and number of days to form roots of Rosa cv. Eiffel Tower shoots. The results are shown in Tables 5 and 6.

Data in Tables 5 and 6 indicate that culturing the shoots on a medium at a $\mathrm{pH}$ level of 5.5 significantly increased the rooting percentage up to $72 \%$ and accelerated root formation (11.50 days). No significant effect of $\mathrm{pH}$ medium was observed on root length, nevertheless, medium $\mathrm{pH}$ at 5.5 reduced the root number to 4.61 roots per shoot in comparison to shoots cultured on $\mathrm{pH}$ medium of 5 which produced 6 roots per shoots.
The obtained data in Tables 5 and 6 indicate that increasing sucrose concentrations up to 50 $\mathrm{g} / \mathrm{l}$ significantly increased rooting percentage $(80 \%)$, root length $(1.92 \mathrm{~cm})$ and enhanced the root formation in 7 days compared to medium supplemented with $30 \mathrm{~g} / 1$ (16.17 days). No significant effect of sucrose was observed on number of roots.

It appears from the data presented in Tables 5 and 6 and Fig. 3 that the medium with pH 5.5 supplemented with $50 \mathrm{~g} / 1$ sucrose produced the highest significant value of root percentage (85\%) and enhanced root formation in 7.5 days. No significant interaction effects were observed on root number and root length. 
Acclimatization and field establishment

Well-developed in vitro-rooted healthy plantlets with 1-2 leaves were successfully acclimatized according to the protocol followed under the conditions of the current experiment. After the plantlets were transferred to plastic pots containing mixture of peat: perlite (1:1 $\mathrm{v} / \mathrm{v}$ ), they were kept in a growth chamber under $16 / 8 \mathrm{~h}$. photoperiod, at a temperature of
$20 / 25^{\circ} \mathrm{C}$ (night/day) and $80 \%$ humidity. After one month, the survival rate of $55 \%$ was recorded. Survived plantlets were placed under plastic greenhouse conditions $\left(25{ }^{\circ} \mathrm{C}\right.$ and $\left.80 \% \mathrm{RH}\right)$ for acclimatization. After 6 month, the plantlets with shoot length $\sim 22 \mathrm{~cm}$ and 5.50 leaves/shoot, on average, were transferred to big plastic pots containing clay and kept outside the green house (Fig. 4).

TABLE 5. Effect of medium $\mathrm{pH}$ and sucrose on rooting\% and number of roots during in vitro rooting stage of Rosa hybrida. cv. Eiffel Tower

\begin{tabular}{|c|c|c|c|c|c|c|}
\hline \multirow[b]{2}{*}{ sucrose g/l } & \multicolumn{3}{|c|}{ Rooting \% } & \multicolumn{3}{|c|}{ Number of roots } \\
\hline & 5 & 5.5 & Mean & 5 & 5.5 & Mean \\
\hline 30 & 62.00 & 61.00 & 61.50 & 7.33 & 5.00 & 6.17 \\
\hline 40 & 65.00 & 70.00 & 67.50 & 5.67 & 3.67 & 4.67 \\
\hline 50 & 75.00 & 85.00 & 80.00 & 5.00 & 5.17 & 5.09 \\
\hline Mean & 67.33 & 72.00 & & 6.00 & 4.61 & \\
\hline
\end{tabular}

LSD 0.05

$\begin{array}{lcc}\mathrm{pH} & 1.18 & 1.07 \\ \text { Sucrose } & 1.44 & \text { N.S* } \\ \mathrm{pH} \text { x sucrose } & 2.04 & \text { N.S }\end{array}$

* NS= not significant at $p<0.05$ by LSD

TABLE 6. Effect of medium $\mathrm{pH}$ and sucrose on root length and number of days to form roots during in vitro rooting stage of Rosa hybrida. cv. Eiffel Tower

\begin{tabular}{|c|c|c|c|c|c|c|}
\hline \multirow[b]{2}{*}{ sucrose $\mathrm{g} / \mathbf{l}$} & \multicolumn{3}{|c|}{ Root length $(\mathrm{cm})$} & \multicolumn{3}{|c|}{ Number of days to form roots } \\
\hline & 5 & 5.5 & Mean & 5 & 5.5 & Mean \\
\hline 30 & 1.00 & 1.00 & 1.00 & 17.33 & 15.00 & 16.17 \\
\hline 40 & 1.50 & 1.33 & 1.42 & 12.33 & 12.00 & 12.17 \\
\hline 50 & 2.00 & 1.83 & 1.92 & 6.50 & 7.50 & 7.00 \\
\hline Mean & 1.50 & 1.39 & & 12.05 & 11.50 & \\
\hline \multicolumn{7}{|l|}{ LSD 0.05} \\
\hline $\mathrm{pH}$ & & NS* & & & 0.68 & \\
\hline Sucrose & & 0.19 & & & 0.48 & \\
\hline $\mathrm{pH} \times$ sucrose & & NS & & & 1.18 & \\
\hline
\end{tabular}

* NS $=$ not significant at $p<0.05$ by LSD 

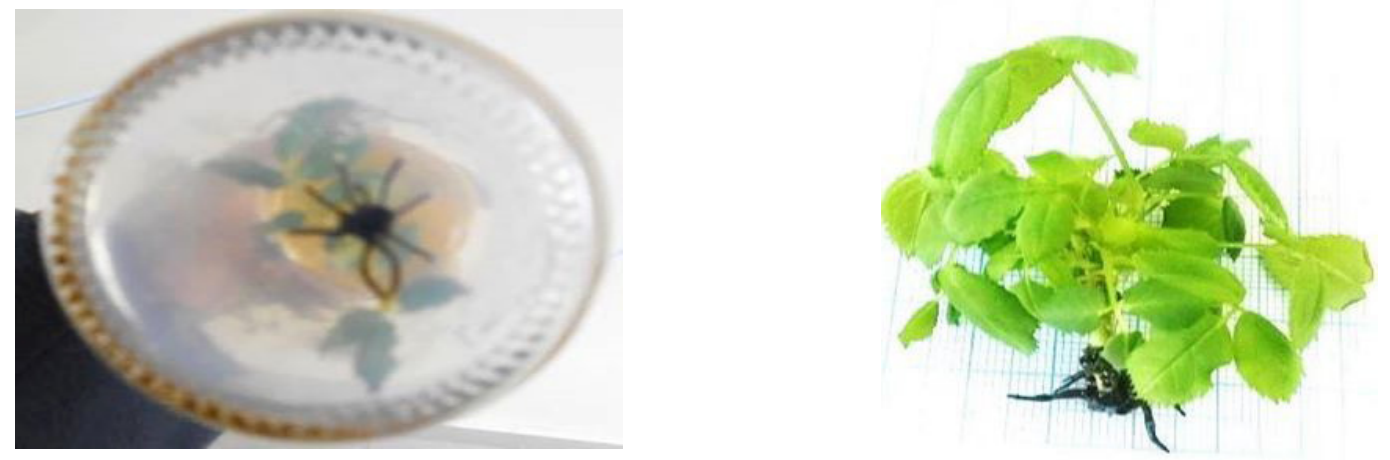

$30 \mathrm{~g} / \mathrm{l}$ sucrose and medium pH 5.5
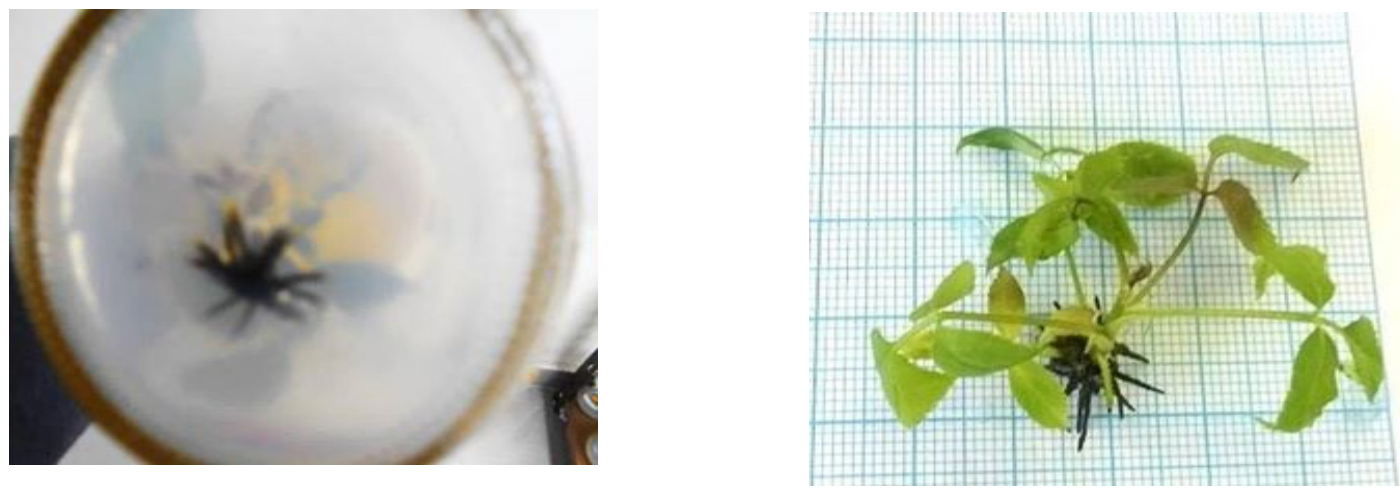

$40 \mathrm{~g} / \mathrm{l}$ sucrose and medium pH 5

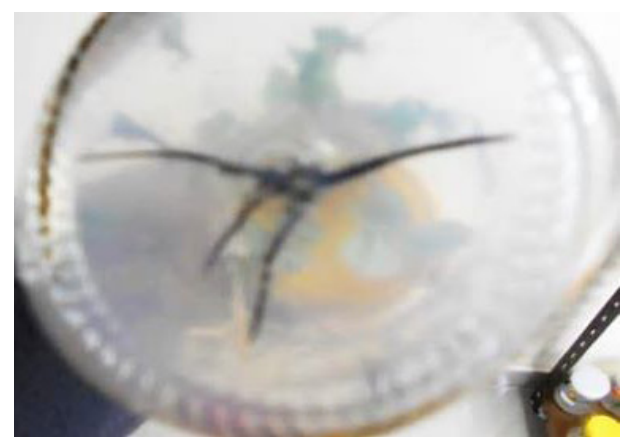

$50 \mathrm{~g} / \mathrm{l}$ sucrose and medium pH 5
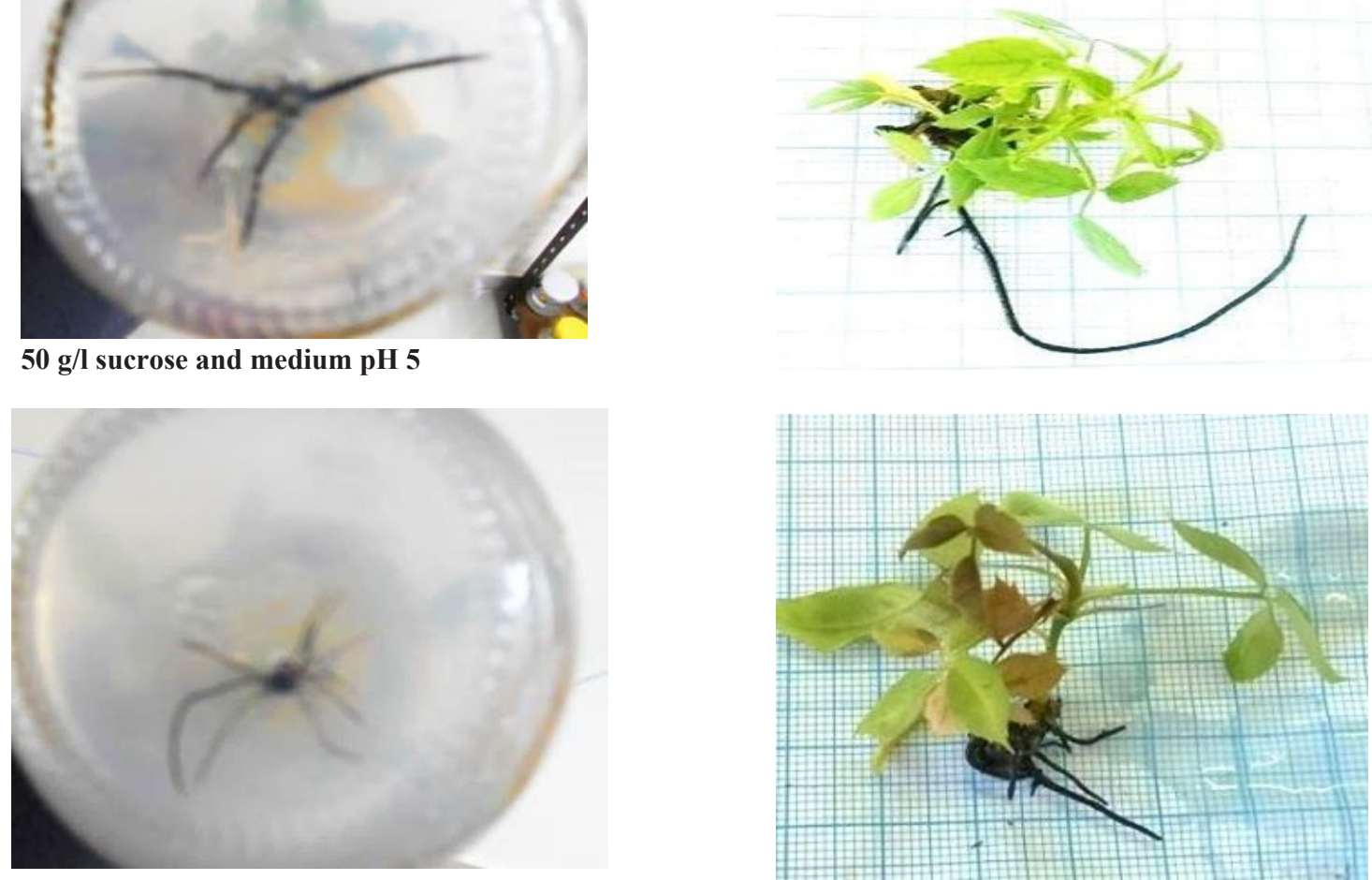

$50 \mathrm{~g} / \mathrm{l}$ sucrose and medium $\mathrm{pH} 5.5$

Fig. 3. Effect of interaction between $\mathrm{pH}$ and sucrose at different concentrations on rooting behavior of Rosa hybrida cv. Eiffel Tower shoots 

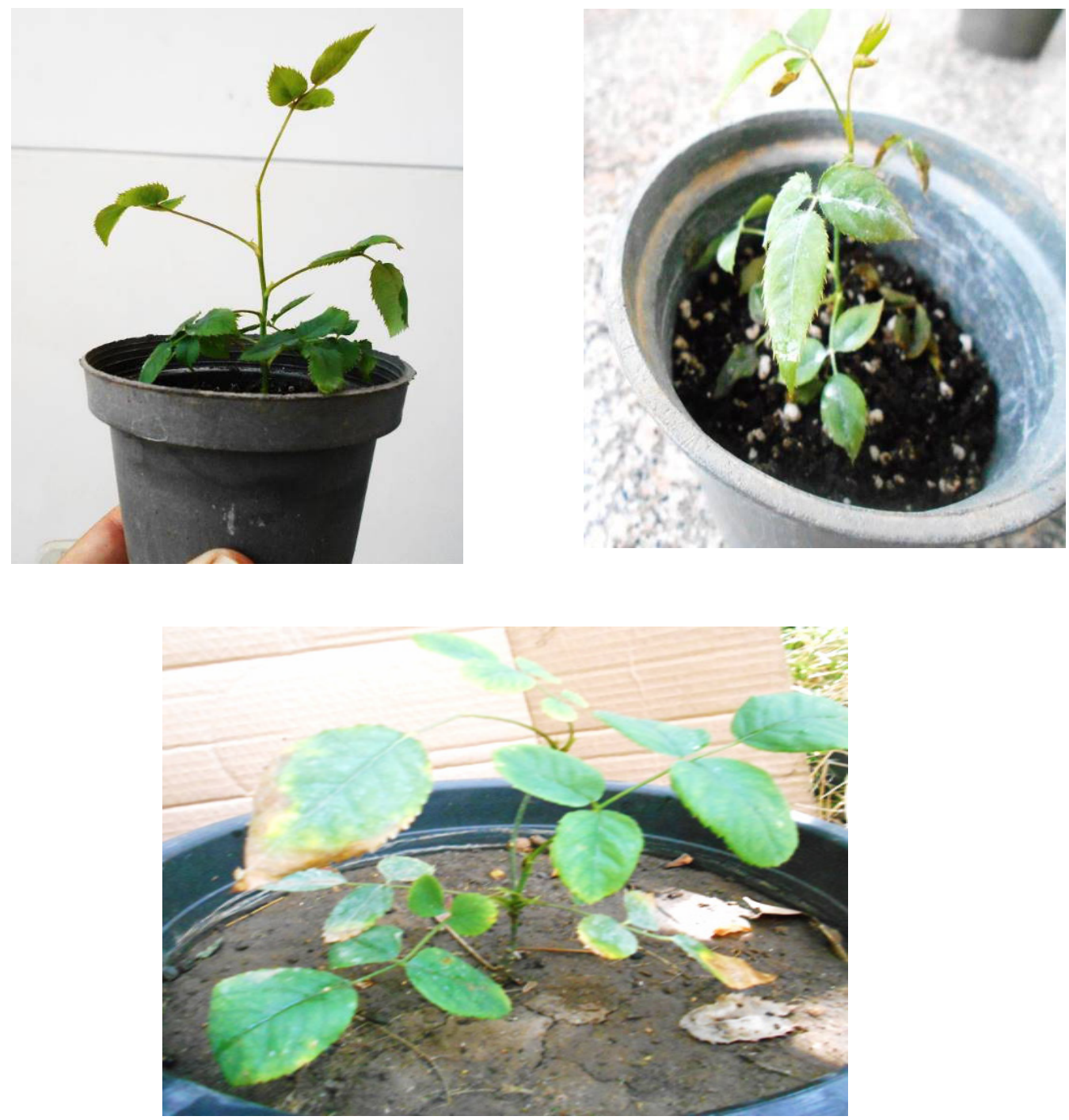

Fig. 4. Acclimatization of in vitro-derived plantlets of Rosa hybrida cv. Eiffel Tower

\section{Conclusion}

Nodal segments of Rosa spp. cv. Eiffel Tower were successfully established and multiplied on MS medium supplemented with BAP at $1 \mathrm{mg} / \mathrm{l}$ plus kinetin at $0.5 \mathrm{mg} / \mathrm{l}$. High rooting percentage and fast rooting were obtained through adjusting auxin concentration, sucrose and medium $\mathrm{pH}$ value. Rooted shoots were successfully acclimatized.

Acknowledgments: the authors are grateful to employees and technicians at Department of Ornamental Plants Faculty of Agriculture, Assiut University for technical assistance and their help throughout the course of the study.

Egypt. J. Hort. Vol. 45, No. 2 (2018)
Funding statements: the authors would like to thank the Higher Administration of Assiut University for the financial support of this study.

Conflicts of interest: the authors declare that there are no conflicts of interest related to the publication of this study

\section{References}

Ahmad, T., Hafeez-ur-Rahman, Ahmed, C.M.S. and Laghari, M.H. (2003) Effect of culture media and growth regulators on micro-propagation of peach rootstock GF 677. Pak. J. Bot., 35, 331-338. 
Ahmed, S., Sharma, A., Bhushan, B., Singh, A.K. and Wali, V.K. (2014) Effect of carbohydrate source, $\mathrm{pH}$ and supporting media on in vitro rooting of banana (Musa spp.) cv. Grand Nain plantlets. Afr. J. Agric. Res., 9, 1135-1140.

Ambros, V.E., Vasilyeva, Y.O. and Novikova, T.I.V. (2016) Effects of in vitro propagation on ontogeny of Rosa canina L. micropropagated plants as a promising rootstock for ornamental roses. Plant Cell Biotechnol. Mol. Biol., 17, 72-78.

Bagheri, M.S., Saidi, A., Jari, S.K., and Goodarzi, G. (2015) Effects of different hormonal concentrations on damask rose (Rosa damascena Mill.) micropropagation in liquid tissue culture medium. Int. J. Biosci., 6, 10-16.

Brunda, S. M., Rani, C. L., Rajendran, P., Smitha, R., and Priya, L. (2016) In vitro propagation of Rosa hybrida 'Golden Fairy' through nodal explants. In International Symposium on Succulents and Other Ornamentals, Ambalavayal, Wayanad, Kerala, India, 2016, Rajendran, P., Revi, S., Vishnu Savanth, V. (Eds.), ISHS Acta Hortic., 1165, 87-90.

De Klerk, G., Hanecakova, J. and Jasik, J. (2008) Effect of medium-pH and MES on adventitious root formation from stem disks of apple. Plant Cell Tissue Organ Cult., 95, 285-292.

Gabryszewska, E.A. (2015) Effect of different sucrose and nitrogen salt levels in the medium and temperature on in vitro propagation of Helleborus niger L. Acta Agrobot., 68, 161-171.

Gomez, K.A. and Gomez, A.A. (1984) Statistical Procedures for Agricultural Research, $2^{\text {nd }}$ ed. John Wily, NY., 680 p.

Hamama, L., Cesbron, D., Voisine, L., Lecerf, M., Jareno, C., Dorion, N., and Oyant, H.S. (2015) Effects of carbohydrate sources and BAP concentrations on in vitro morphogenesis of four rose genotypes. Acta Hortic., 1083, 75-83

Hameed, N., Shabbir, A., Ali, A. and Bajwa, R. (2006) In vitro micropropagation of disease free rose (Rosa indica L.). Mycopath., 4, 35-38.

Hasan, N.A., Hussein, S.B. and Ibrahim, R. (2015) Effect of medium $\mathrm{pH}$ and sucrose concentrations on adventitious roots induction of Labisia pumila. Proceedings of the IRES $14^{\text {th }}$ International Conference, Paris, France, $7^{\text {th }}$ November, 2015, 44-48.

Hasegawa, P.M. (1979) In vitro propagation of rose. Hortic. Sci., 14, 610-612.
Hegde, V., Kag, B., Sathyanarayana, B.N. and Sharath, R. (2011) Rapid in vitro multiplication and shoots regeneration from nodal explants of rose. Journal of Cell and Tissue Research, 11, 2961-2965.

Ibrahim, R. and Debergh, P.C. (2001) Factors controlling high efficiency adventitious bud formation and plant regeneration from in vitro leaf explants of roses (Rosa hybrida L.). Sci. Hortic., 88, 41-57.

Kanchanapoom, K., Posayapisit, N. and Kanchanapoom, K. (2009) In vitro flowering from cultured nodal explants of rose (Rosa hybrida). Not. Bot. Hort. Agrobot. Clu. J., 37, 261-263.

Kharde, A.V. and Kshirsagar, A.B. (2014) Effect BAP and Kinetin on nodal culture of Rosa hybrida L. Bionano Frontier, 7, 254-257.

Kovacevic, B., Miladinovic, D., Katanic, M., Tomovic, Z. and Pekee, S. (2013) The effect of low initial medium $\mathrm{pH}$ on in vitro with poplar growth. Biblid, 108, 67-80.

Kroin, J. (2016) Propagation of Roses: Stenting Simultaneously Cutting and Grafting. Hortus USA Article. Available online: http://www.rootinghormones.com/IBAarticles/Propagation_of_roses by_Stenting.pdf (accessed in May 2018).

Kumari, S., Singh, K. P., Singh, S. K., Kumar, S. and Sarkhel, S. (2017) Establishment of in vitro propagation protocol for Hybrid Tea rose cv. Raktagandha. The Horticultural Society of India (Regd.), 74, 245-250.

Kumud, S., Hem, P., and Vijay, R. (2015) Micropropagation of rose cultivars: Biotechnological application to floriculture. Journal of Environmental Research and Development, 10, 40.

Mahmood, S. and Hauser, B. (2015) Influence of cytokinins on the shoot proliferation and subsequent rooting in rose. Asian Journal of Agricultural Research, 9, 259-267.

Manners, M. M. (2014): Propagation roses from cuttings, Florida Southern College. Available online: http://www.rkdn.org/roses/propagate.asp (accessed in May 2018).

Martins, N., Goncalves, S., Palma, T. and Romano, A. (2011) The influence of low $\mathrm{pH}$ on the in vitro growth and biochemical parameters of Plantago almogravensis and P. algarbiensis. Plant Cell Tissue Organ Cult., 107, 113-121. 
Maurya, R.P., Yadav, R.C., Godara, N.R. and Beniwal, V.S. (2013) In vitro plant regeneration of rose (Rosa hybrida) cv. Benjamin Paul through various explants. Journal of Experimental Biology and Agricultural Sciences, 1, 111-119.

McGaw, B.A. and Burch, L.R. (1995) Cytokinin Biosynthesis and Metabolism. In: Davies, P.J. (Ed.) Plant Hormones: Physiology, Biochemistry and Molecular Biology, Kluwer Academic Publishers, Dordrecht, 98-117.

Murashig, T. and Skoog, F. (1962) A revised medium for rapid growth and bioassay with tobacco tissue culture. Physiol. Plant., 15, 473-497.

Pati, P.K., Rath, S.P., Sharma, M., Sood, A. and Ahuja, P.S. (2006) In vitro propagation of rose -a review. Biotechnol. Adv., 24, 94- 114.

Rose Society (2012): Eiffel Tower. Available online: http://sarose.org.au/rose-month/eiffel-tower/ (Accessed in May 2016).

Schum, A., Hofmann, K., Ghaalib, N., and Tawfik, A.A. (2001) Factors affecting protoplast isolation and plant regeneration in Rosa spp. Gartenbauwissenschaft, 66,115-122.

Shang, X.M., Huang, J.Y., Haigler, C.H. and Trolinder, N.L. (1991) Buffer capacity of cotton cells and effects of extracellular $\mathrm{pH}$ on growth and somatic embryogenesis in cotton cell suspensions. In Vitro Cell. Dev. Plant, 27, 147-152.

Tawfik, A.A., Read, P.E. and Cuppett, S.L. (1992) Effect of some nutritional factors on monoterpene synthesis in Rosmarinus officinalis cultured in vitro. Acta Hort., 319, 189-191.

Tawfik, A.A. and Noga, G. (2001) Adventitious shoot proliferation from hypocotyl and internodal stem explants of cumin. Plant cell Tissue organ cult., 66,141-147.

Tawfik, A.A. (2002) Adventitious meristem organogenesis and shoot proliferation of Salvia officinalis L. in split-nodal culture. Assiut J. Agric. Sci., 33, 99-114.

Tawfik, A.A. and Mohamed, M. F. (2005) Organogenic response of Salvia officinals L. to dark preconditioning, thidiazuron and benzyladenine. Plant Growth Regul. Soc. Amer. Quarterly, 33, 125-133.

Tawfik, A.A. and Mohamed, M. F. (2006) In vitro cloning of two cumin landrace lines via shoot-tip culture. J. Hort. Sci. \& Biotech., 81, 246-268.
Tawfik, A.A. (1995) In vitro propagation of Melaleuca armillaris. Assiut J. Agric. Sci., 26, 137-149.

Tawfik, A.A. (1997) Micropropagation and plant regeneration of neem tree (Azadirachta indica Juss). Assiut J. of Agric. Sci., 28, 3-14.

Uzunova, K. (2015) Comparative analysis of different rose cultivars (Rosa hybrida L.) rooting using conventional and biotechnology approaches. Annuaire de l'Université de Sofia "St. Kliment Ohridski” Faculte de Biologie, 100, 191-199.

Van Winkle, S. and Pullman, G.S. (2003) The combined impact of $\mathrm{pH}$ and activated carbon on the elemental composition of plant tissue culture media. Plant Cell Rep., 22, 303-311.

Yakimova, E., Toteva, V.K., Groshkoff, I. and Ivanova, G. (2000) Effect of BA and CPPU on protease and $\alpha$ amylase activity of in vitro cultured explants of Rosa hybrida L. Bulg. J. Plant Physiol., 26, 39-47.

(Received 26/08/2018, accepted 19/10/2018)

Egypt. J. Hort. Vol. 45, No. 2 (2018) 


\section{عمل بروتوكول إكثار دقيق لنبات الورد صنف برج إيفل يتميز بقرة تجذيرية عالية داخل

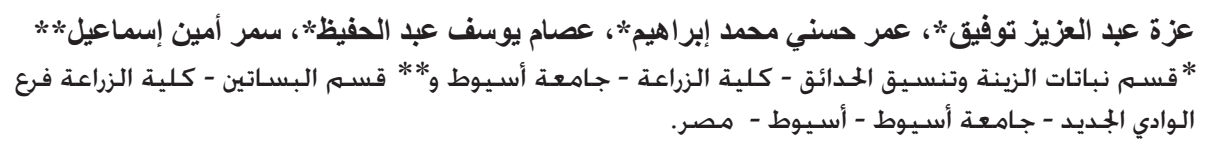

تمت در اسة بعض تقنيات الإكثار الاقيق بهدف تعظيم بروتوكول للإكثار على نطاق و اسع وسريع لنبات الورد

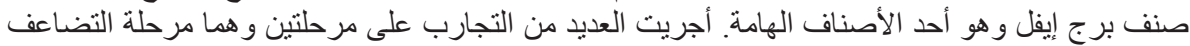

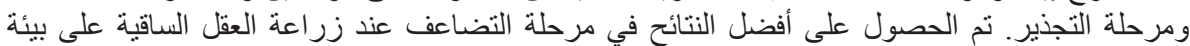

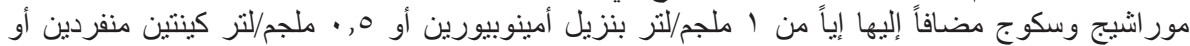

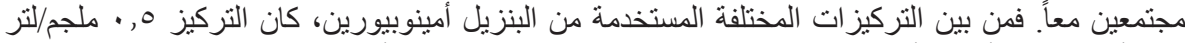

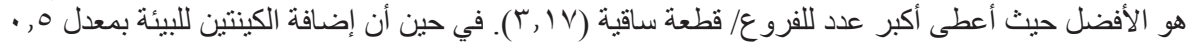

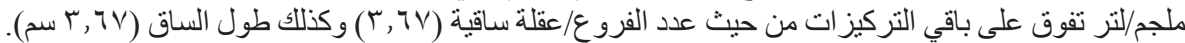

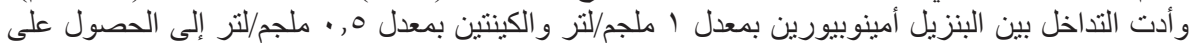

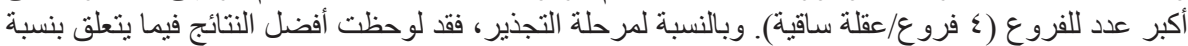

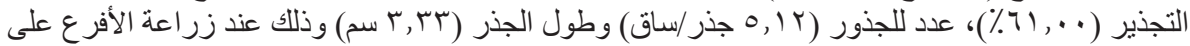

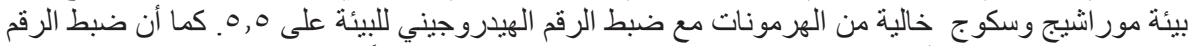

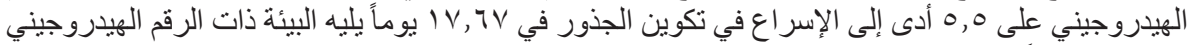

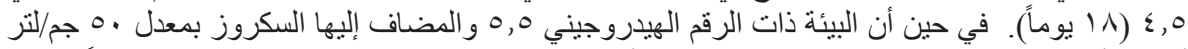

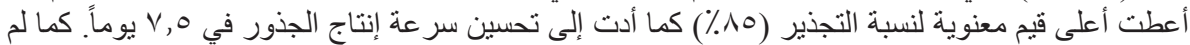

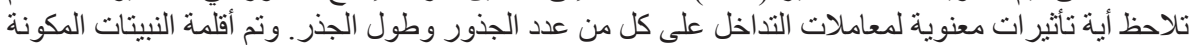

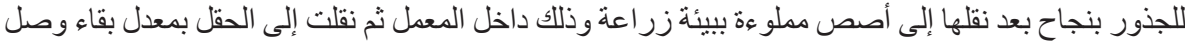

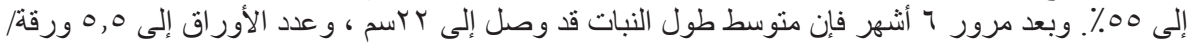

